\title{
Europese waarden in de les godsdienst/ levensbeschouwing
}

\section{Een verkenning van de mogelijkheid het materiaal van het European Values Education project in te zetten in het vak godsdienst/levensbeschouwing}

Gijs van Gaans*

\section{Summary}

European students and teachers both seem to lack a precise knowledge of European Values. The European Value Education (EVE)-project therefore developed educational materials that would help secondary teachers to discuss these values in schools. These materials were made available for free online. They were developed in such a manner that would allow teachers to apply them directly in their own classes. The EVE-project envisioned the materials to be also used by teachers of religious education (RE), since the materials discuss topics that are traditionally addressed in RE-classes. However, no RE-teachers were involved in the EVE-project. Recently, value education, especially in the context of citizenship education, has received more attention in the Dutch curriculum as a whole and the RE-curriculum in particular. The EVE-materials could help teachers in secondary education to study values together with their students. This paper analyses the didactic activities and sources provided by the EVE-project in order to ascertain their usefulness for Dutch teachers of RE. It analyses the ways the materials support their goals and the way they approach the topic of religion in order to provide some guidepost on how to use them in the Dutch RE-classroom.

\section{Inleiding}

Veel Europese jongeren weten nauwelijks hoe in Europa over belangrijke waarden wordt gedacht en hoe de Europese landen daarin onderling verschillen. Ook bij leraren in het voortgezet onderwijs lijkt deze kennis beperkt aanwezig, zeker wanneer het gaat om landen buiten West-Europa. Om docenten in het voortgezet onderwijs, met name die van de mens-en-maatschappijvak-

* Gijs van Gaans is docent en vakdidacticus bij de vakgroepen levensbeschouwing en geschiedenis, Fontys Lerarenopleiding Tilburg. 
ken, te ondersteunen bij het lesgeven over Europese waarden, verwerkte een internationale projectgroep de uitkomsten van de European Value Study (EVS) tot lesmateriaal. ${ }^{1}$ Dit lesmateriaal bestaat allereerst uit toegankelijk gemaakte data uit de EVS, maar ook uit lesbrieven die direct in de klas gebruikt zouden kunnen worden. ${ }^{2}$

Al in november 2011 publiceerden enkele docenten van de Fontys Lerarenopleiding Tilburg (FLOT) een handreiking met de titel Van onderzoek tot lesmateriaal. European Values Education (EVE). Deze publicatie (Krause et al. 2011) biedt een eerste kennismaking met het materiaal van het EVEproject. Daarbij geeft ze enkele handreikingen hoe docenten aardrijkskunde, geschiedenis, maatschappijleer, economie en moderne vreemde talen, de lesmaterialen in kunnen zetten in hun eigen lessen. Bij het ontwerpen van het EVE-materiaal waren echter nauwelijks docentenopleiders godsdienst/levensbeschouwing betrokken. Omdat de opleiding godsdienst en levensbeschouwing in 2011 nog geen onderdeel vormde van FLOT, heeft ook geen van haar docenten een bijdrage kunnen leveren aan genoemde publicatie. Deze biedt derhalve geen handreikingen voor docenten godsdienst/levensbeschouwing. Dit artikel is een eerste verkenning van de bruikbaarheid van het ontwikkelde materiaal voor dit schoolvak

Op dit moment lijkt er in het Nederlandse onderwijs steeds meer aandacht te komen voor waardeneducatie als onderdeel voor de burgerschapsvorming. Deze toegenomen aandacht blijkt onder andere uit het tussenproduct van het ontwikkelteam 'burgerschap' van curriculum.nu. Deze en andere ontwikkelteams zijn in het leven geroepen in opdracht van de overheid. Zij hebben als taak een nieuw curriculum te ontwerpen voor verschillende aandachtsgebieden in zowel het primair onderwijs, als in de onderbouw van het middelbaar onderwijs. In hun ontwerpproces hebben zij onlangs enkele zogenaamde 'grote opdrachten' geformuleerd, hetgeen slaat op de grote maatschappelijke opdrachten van het onderwijs in de betreffende aandachtsgebieden. In de geformuleerde 'grote opdrachten' stelt het team burgerschap expliciet dat de waarden vrijheid, gelijkheid en solidariteit de basis voor deze opdrachten vormen. Verder benadrukt het team het belang van dialoog tussen leerlingen, waarin aandacht voor elkaars mening en waarden een belangrijke rol speelt. Daarnaast benadrukt ook het ontwikkelteam 'mens en maatschappij' de noodzaak van waardeneducatie, onder andere in de vaardigheid 'denken vanuit anderen'. Onder die vaardigheid wordt verstaan dat leerlingen meerdere perspectieven op basis van verschillende levensovertuigingen en politieke of persoonlijke opvattingen kunnen hanteren. ${ }^{3}$ Juist deze nieuwe uitgangs- 
punten voor een nieuw nationaal curriculum bieden aanknopingspunten voor het gebruik van het EVE-materiaal.

Op dit moment wordt ook binnen het schoolvak levensbeschouwing gewerkt aan een nieuw kerncurriculum, een curriculum dat kan dienen als basis voor het schoolvak op alle scholen waar het vak ook daadwerkelijk gegeven wordt. De vakvereniging voor docenten levensbeschouwing en godsdienst (VDLG) speelt in deze ontwikkeling een belangrijke rol. Een laatste, voorlopig, concept voor dit kerncurriculum kwam tot stand mede op basis van brainstormbijeenkomsten met mensen uit het onderwijsveld, georganiseerd op verschillende plekken in heel het land. Deze vakmensen, naast docenten ook docentenopleiders en andere geïnteresseerden, benadrukten de waarde van het (persoons)vormende doel van het schoolvak, in levensbeschouwelijke zin. Daaronder wordt verstaan 'het omgaan met levensbeschouwelijk anderen in de multiculturele samenleving', hetgeen niet enkel, maar zeker ook de levensbeschouwelijke waarden van die anderen betreft. Een van de kernvaardigheden in het voorgestelde curriculum is dan ook het 'levensbeschouwelijk zingeven', waaronder de deelvaardigheid 'waardenreflectie' valt (Visser, Van der Zande, Schelberg \& Van der Heijden 2018).

Veel scholen lijken het vak godsdienst/levenbeschouwing een belangrijke rol toe te kennen bij het bereiken van de burgerschapsdoelen. Een aantal scholen heeft het vak geïntegreerd in een combinatievak samen met andere mens-en-maatschappijvakken, bijvoorbeeld onder de naam 'global learning.' In beide gevallen heeft het vak juist met betrekking tot waardeneducatie zeker veel te bieden aan het moderne onderwijs. De vraag is of het EVE-materiaal, met name de kant-en-klare lesbrieven, ook voor het vak godsdienst/levensbeschouwing geschikt is.

In deze bijdrage zal eerst kort worden ingegaan op de ontwikkeling van het lesmateriaal door het projectteam. Daarbij zal worden besproken welke doelen dat team had, welke keuzes het maakte en welke didactische ontwerpprincipes het hanteerde. Daarna zal aan de hand van enkele concrete voorbeelden worden bepaald in welke mate het materiaal aansluit bij de doelen en uitgangspunten van het vak godsdienst/levensbeschouwing en welke uitdagingen daaruit volgen. Uiteindelijk zullen enkele handvatten worden gegeven hoe docenten het materiaal uiteindelijk in hun eigen les kunnen inzetten. 


\section{De ontwikkeling van het EVE-project}

De resultaten van een grootschalig empirisch surveyonderzoek als de EVS zijn niet direct bruikbaar in de klas. Daarom zette het EVE-project deze data allereerst om naar leermiddelen, die wel geschikt waren voor het middelbaar onderwijs. De projectleden - naast docenten van FLOT ook docenten van internationale partners - vermoedden dat veel docenten onvoldoende tijd en soms ook inzicht hadden om werkvormen te ontwikkelen. Daarom schreven zij enkele activerende werkvormen uit, die verwerkt werden in lesbrieven.

Al deze ontwikkelde materialen moesten in de (hele) Europese context gebruikt kunnen worden. Daarom kozen de projectleden ervoor het materiaal digitaal en gratis aanbieden. Om een brede verspreiding mogelijk te maken werd er bovendien voor gekozen om alles in verschillen talen te vertalen. In eerste instantie is gekozen voor de talen van alle deelnemende partners (Engels. Slowaaks, Duits, Turks en Nederlands). Daarnaast werd het materiaal tevens in het Frans en Spaans vertaald. Het doel is om de materialen in de toekomst in nog meer Europese talen te vertalen.

\section{Het materiaal: kaarten en video's}

Het EVE-project koos ervoor om de overzichtskaarten op basis van EVS gegevens te gebruiken. Deze geografische afbeeldingen geven de gemiddelden uit het onderzoek per land weer. De kaarten geven dus per land maar één 'score', vaak uitgedrukt in tinten van dezelfde kleur. De kaarten vormen bruikbare leermiddelen, geschikt voor verschillende lessituaties. Omdat ze voor leerlingen wat abstract of 'droog' kunnen zijn, werd besloten een aantal video's op te nemen. Daarin werden jongeren uit verschillende EU landen geïnterviewd over de thema's die ook in het EVS zijn bevraagd. Deze video's zijn bedoeld om de waardeneducatie levendiger te maken. Zoals vermeld, biedt het EVE-project ook enkele lesbrieven aan. Zowel de video's als de activerende lesbrieven zijn gericht op een pluriformiteit van meningen. Zij bevorderen het formuleren en ondervragen van een eigen standpunt en concentreren zich daarom ook op de relevante metacognitieve vaardigheden. De genoemde overzichtskaarten moesten wel nog toegankelijk gemaakt worden. Allereerst werden ze gedigitaliseerd, want een papieren atlas is immers niet overal even betaalbaar (Halman, Sieben \& Van Zundert 2011).

De keuze voor deze kaarten bezorgde de projectleden enkele uitdagingen bij het ontwerpen van de lesbrieven. Een eerste uitdaging school in de verschillende antwoordschalen van de afzonderlijke kaarten. Omdat dezelfde kleur in verschillende kaarten verschillende percentages weergeven, zijn 
deze onderling niet meteen gemakkelijk te vergelijken. Dezelfde kleur op verschillende kaarten duidde immers een andere waarde aan. Leerlingen moest duidelijk worden gemaakt hoe ze de verschillende kaarten moesten lezen. Daarbij geven de kaarten enkel de nationale gemiddelden weer, waardoor regionale verschillen onzichtbaar zijn. Die regionale verschillen zijn er wel degelijk. Er kunnen voor het EVS onderzoek van 2008 wel kaarten met regionale gegevens worden vervaardigd, maar deze zijn niet opgenomen in het aangeboden lesmateriaal.

\section{Didactische uitgangspunten}

Het projectteam wilde niet alleen lesbrieven voor de mens-en-maatschappijvakken in het voorgezet onderwijs (aardrijkskunde, geschiedenis, economie en maatschappijleer) ontwikkelen die in zoveel mogelijk Europese landen inzetbaar moesten zijn, het wilde in die lesbrieven tevens activerende werkvormen aanbieden die de leerlingen in staat zouden stellen zichzelf tot verschillende waarden te verhouden. Bij het ontwerpen werkte het team daarom vanuit de zogenaamde implicatiesamenhang (Meyer \& Jank 2009). Deze stelt dat docenten leerdoelen, leermiddelen, werkvormen en inhoud zinvol en kloppend in hun les samenbrengen.

De lesbrieven zijn in principe geschreven vanuit concrete leerdoelen. Vanuit de doelen selecteerde de projectgroep doorgaans die kaarten die het best aansloten bij dat doel. Vanwege de hoge kwaliteit van de kaarten, werd dit vertrekpunt in het begin helaas nog wel eens uit het oog verloren. Leden van het projectteam ontwierpen de lesbrieven dan vanuit de kaarten in plaats vanuit doelen. Daarom zetten zij kaartvaardigheden soms iets te gemakkelijk als (extra) doel in. Vanuit didactisch oogpunt is dat niet de koninklijke route. Desondanks zijn alle lesbrieven wel ontworpen om een viertal algemene en opeenvolgende leerdoelen te bereiken.

Allereerst leren leerlingen, door kaarten en video's te bestuderen, om te bepalen welke verschillen er qua waarden in Europa bestaan en leren zij hun eigen mening en opvattingen te betrekken bij dit bestuderen. De kaarten bieden uiteraard feitelijke informatie, maar leerlingen worden wel uitgedaagd om te verwoorden wat ze er zelf van vinden. Vervolgens leren leerlingen de verschillen en overeenkomsten tussen verschillende landen te verwoorden, maar uiteindelijk ook te duiden. Uiteindelijk dienen zij op basis van kritische oordelen en reflectie een eigen, bijgesteld standpunt te ontwikkelen.

Om de leerlingen bij de thema's te betrekken zijn de lesbrieven opgebouwd rond zo prikkelend mogelijke onderzoeksvragen, zoals 'Is voetbal even belangrijk als religie?' Het idee is dat een goede onderzoeksvraag zowel prikkelt tot 
zelfstandige studie ('Ik wil hier een mening over hebben') als voldoende diepgang biedt om de complexiteit van een bepaald thema recht te doen ('Maar ik moet ook wel zaken zelf afwegen om een geldige reden te kunnen verwoorden.'). Een dergelijke aanpak kent een langere traditie in de schoolvakken aardrijkskunde en geschiedenis, met name in de Angelsaksische wereld (Phillips 2008). Het hieronder weergegeven kader geeft een voorbeeld van een lesbrief.

\section{Is voetbal even belangrijk als religie?}

Een voorbeeld van een lesbrief voor leerlingen van ca. 15-16 jaar draait om de eerdergenoemde vraag 'Is voetbal even belangrijk als religie? ${ }^{\text {4‘ }}$ Deze lesbrief start met een beroemde uitspraak van Bill Shanklin.

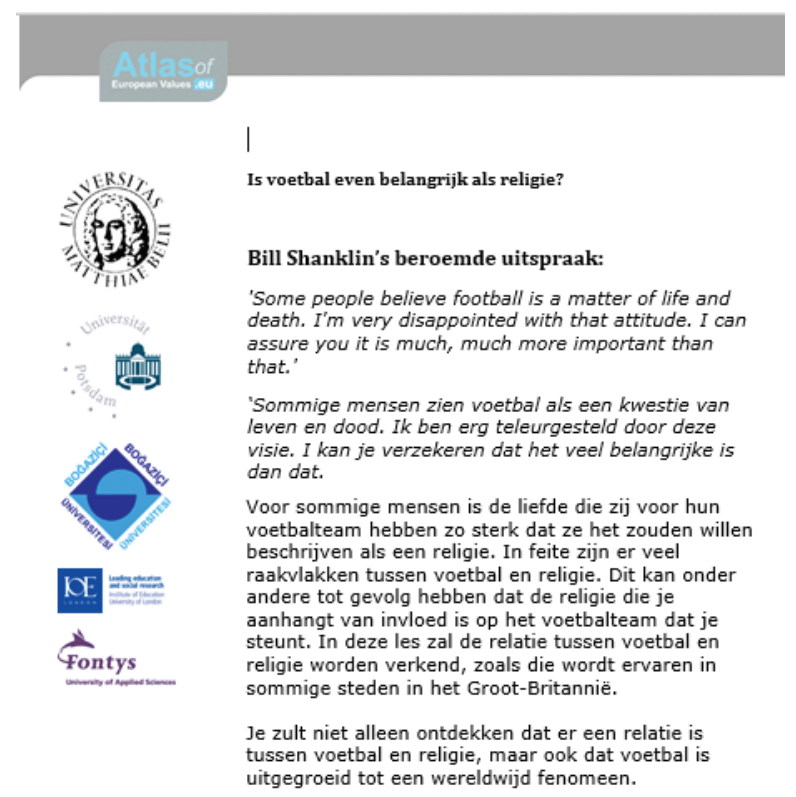

De lesbrief laat de leerling eerst de verschillen tussen de aanhang van de voetbalploegen van Manchester United en Glasgow Celtic analyseren in relatie met de katholieke identiteit van veel van hun aanhangers. Vervolgens worden leerlingen uitgedaagd om de eventuele relatie tussen het steunen van een voetbalploeg en de katholieke achtergrond te vergelijken met hun eigen verwachtingen en met andere gegevens met de vraag of deze relatie wel geloofwaardig is. Daarna krijgt de leerling de volgende opdracht: 

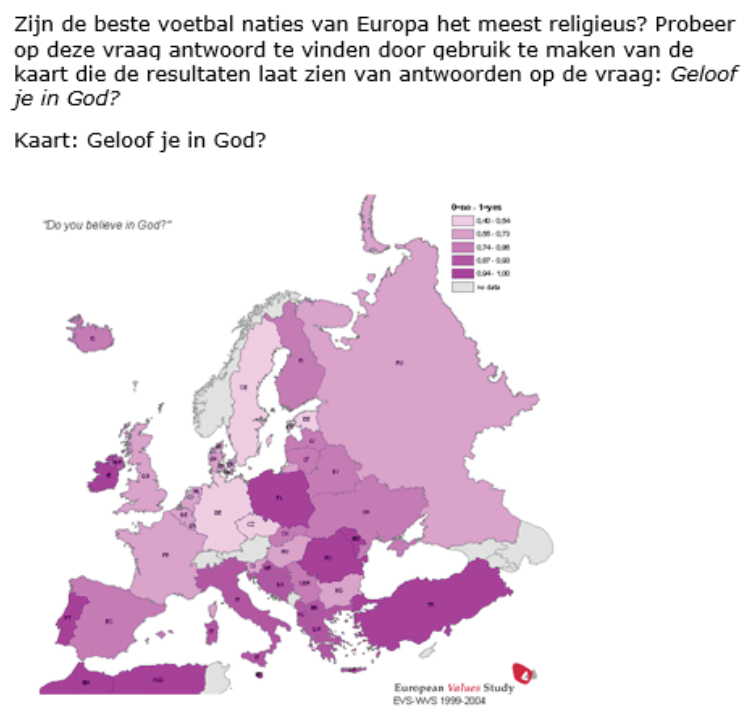

Uiteindelijk wordt de leerlingen gevraagd om deze laatste inzichten weer te vergelijken met eerdere opvattingen. Zo wordt geprobeerd om een dieper inzicht te geven in het mogelijke religieuze karakter van voetbal.

\section{Mogelijke problemen met het EVE-materiaal voor het levensbeschouwelijk onderwijs}

Het lesmateriaal wordt aangeboden in meerdere categorieën: religie, werk, familie en samenleving. De categorie 'religie' is op het eerste gezicht ook voor docenten godsdienst/levensbeschouwing relevant. Toch schiet het materiaal op enkele punten tekort wil het ingezet worden in de lessen godsdienst/ levensbeschouwing, zoals deze op veel scholen gegeven worden. Hieronder wordt op twee belangrijke tekortkomingen verder ingegaan: het verklarende karakter van de lesbrieven en de rol die de seculariseringsthese speelt in sommige lesbrieven.

\section{Het verklarende karakter}

Veel van de beschikbare lesbrieven leggen de nadruk op het verklaren van verschillen binnen Europa. Zo laat de beschreven lesbrief Is voetbal even belangrijk als religie? leerlingen het verband tussen religiositeit en aanhang van 
voetbalploegen analyseren. Bij een andere lesbrief, met de titel Is er een plek in de hemel voor iedere pinguïn? ${ }^{5}$ wordt de leerling gevraagd om het verband tussen onder andere religiositeit, opleidingsniveau en BNP enerzijds en de acceptatie van homoseksualiteit anderzijds te onderzoeken, om zodoende te verklaren waarom homoseksualiteit in het ene Europese land meer geaccepteerd wordt dan het andere.

In veel lessen godsdienst/levensbeschouwing vormt seksualiteit ook een belangrijk onderwerp, maar wordt dit thema naar mijn inzicht anders aangevlogen. Het verschil in aanpak is terug te voeren op een verschil in wetenschappelijke traditie, een verschil dat terug te voeren is op het reeds door Wilhelm Dilthey aangekaarte verschil tussen 'verklaren' (Erklären) en 'verstaan' (Verstehen). Juist bij de bestudering van religie en (religieuze) waarden speelt van oudsher het hermeneutische verstaan een grote rol, zeker in de theologie, de achtergrond van veel docenten godsdienst/levensbeschouwing (McCutcheon 2005). Vaak willen docenten in de lessen levensbeschouwing leerlingen niet alleen laten nadenken over hun eigen standpunt ten opzichte van seksualiteit, maar hen ook leren zich in te leven in andere standpunten. Dit zijn voorwaarden om een ander te kunnen verstaan. De verklaring van de historische veranderingen in seksuele waarden en normen krijgt daarbij doorgaans minder aandacht.

In de schoolpraktijk speelt dat verstaan een grote rol. Clive Erricker (2010), die zich weer baseert op Michael Grimmit, geeft aan dat leerlingen religieuze waarden moeten kunnen 'contextualiseren'. Daarmee bedoelt hij dat leerlingen bijvoorbeeld het verschil in sacraliteit van de Thora binnen verschillende joodse stromingen moet kunnen duiden, om zodoende te kunnen verstaan op welke wijze de Thora heilig is voor verschillende joden en waarom. Hetzelfde gaat op voor religieuze waarden. Bij het vak godsdienst/levensbeschouwing krijgen de verschillen waarin de waarden worden geëxpliciteerd en geïntegreerd in het religieuze leven van verschillende gelovigen en het duiden van die verschillen meer aandacht dan de verklaring van die verschillen of van de historische ontwikkeling ervan (Erricker 2010).

Om de bruikbaarheid van de lesbrieven voor de lessen godsdienst/levensbeschouwing te vergroten moet ook de beleving van de waarden door verschillende Europese bevolkingsgroepen worden besproken. Daarbij moet de wijze waarop zij hun waarden en overtuigingen ten opzichte van een thema als homoseksualiteit verwoorden en tot uitdrukking brengen in hun dagelijkse leven het uitgangspunt zijn. Welke redenen geven veel Russen (61\%) bijvoorbeeld voor het feit dat ze liever niet naast een homoseksueel wonen en welke redenen geven veel Nederlanders (90\%) voor het gegeven dat ze daar geen 
probleem mee hebben? Wat voor amuletten hebben mensen in gedachten wanneer ze zeggen te geloven in de positieve werking ervan? En hoe verhouden amuletten zich tot hun religieuze denken in het algemeen?

Het verstaan van meerdere waarden en de bijbehorende perspectieven sluit ook aan bij een wezenlijk doel voor veel docenten godsdienst/ levensbeschouwing: het aanleren van competenties die een interlevensbeschouwelijke dialoog mogelijk maken. Kees Hamers (2018, 95-97) stelt daarover: 'Interlevensbeschouwelijke dialoog is een middel om leerlingen gevoelig te maken voor andere perspectieven dan die van henzelf.' Daarvoor is het van belang dat leerlingen hun eigen visie en waarden in levensbeschouwelijke taal leren uitdrukken, maar tevens de levensbeschouwelijke aspecten in de taal van anderen leren herkennen. Ook in een dergelijke dialoog spelen waarden een belangrijke rol (Hamers 2018). Het is echter niet de bedoeling te verklaren hoe het komt dat de ander zo denkt, maar om te begrijpen wat die visie en waarden voor hen betekenen.

In een enquête onder Nederlandse docenten godsdienst/levensbeschouwing werd gevraagd om het belang van bepaalde thema's voor mogelijke nationale eindtermen te scoren op een vijfpuntsschaal. De respondenten gaven daarbij een bovengemiddelde score aan het thema 'verschillen begrijpen tussen verschillende vormen van levensbeschouwing' (3,75) (Bertram-Troost $\&$ Visser 2017). Het is dan ook niet verwonderlijk dat deze vaardigheden ook in het eerder genoemde voorstel voor een kerncurriculum zijn opgenomen (Visser et al. 2018).

Het verstaan van de religieuze waarden en overtuigingen, zoveel mogelijk in de eigen woorden van 'anderen' en beschouwd tegen de achtergrond van hun bredere levensbeschouwelijke overtuigingen is dus maar een deel van het verhaal. Bruikbaar lesmateriaal zou tevens de dialoog tussen mensen met verschillende waarden en opvattingen moeten begeleiden en stimuleren. Dat kan in de klas zelf, indien daarin voldoende verschillende levensbeschouwingen aanwezig zijn. De beschikbare lesbrieven zouden in dat geval aangepast moeten worden door leerlingen uit te nodigen echt dieper in te gaan op de vraag waarom ze bepaalde waarden en opvattingen hebben.

\section{De rol van de secularisatiethese}

Een tweede probleem met van het EVE-materiaal schuilt in het verlengde van de verklarende aanpak. Veel van de lesbrieven in de categorie 'religie' vertrekken impliciet of zelfs expliciet vanuit het verklarende model van de secularisatiethese. De aangeboden kaarten bieden antwoorden op vragen, waarin vooral aandacht is voor elementen uit de traditionele, institutionele 
godsdiensten. Religie wordt vooral, doch niet alleen, bevraagd vanuit kerkbezoek, deelname aan gezamenlijke rituelen en traditionele religieuze concepten als 'God', 'Hemel' en 'Hel.'

In de genoemde lesbrief Is er een plek in de hemel voor iedere pinguïn? moeten leerlingen verschillende factoren bespreken die de acceptatie van homoseksualiteit kunnen verklaren. Daarbij volgt uiteindelijk de opdracht zoals gegeven in figuur 1. Hoewel de vraag open is, wordt er toch een duidelijk causaal verband voorgesteld: wanneer meer mensen hoger onderwijs hebben genoten, denken ze zelfstandiger, zijn ze minder afhankelijk van hun mening over homoseksualiteit van religieuze leiders en zullen ze homoseksuelen eerder accepteren. Dit causaal verband lijkt uit te gaan van de theorie van secularisatie. Immers, het berust op de gedachte dat een hoger ontwikkelingsniveau een verklaring biedt voor de afname van het belang van religieuze instituties in het leven van mensen.

\section{Figuur 1 Opdracht 6 uit de lesbrief Is er een plek in de hemel voor iedere pinguïn?}

\section{Opdracht 6:}

Sociale wetenschappers hebben geprobeerd een relatie te verklaren tussen de tolerantie voor homoseksualiteit en religie:

"Als resultaat van het toegenomen niveau van onderwijs worden mensen minder gedwongen door traditionele instellingen omdat mensen hun eigen leven meer kunnen bedingen afgezien van autoritaire instellingen en bemiddeling zoals kerken... Vandaar dat de religieuze controle met betrekking tot de acties van individuen zijn afgenomen en morele en religieuze oordelen voornamelijk gebaseerd zijn op eigen ideeën en persoonlijke beoordelingen." Loek Halman, Universiteit van Tilburg/NL

Kun je bewijzen dat deze stelling klopt aan de hand van de kaarten die je hebt bestudeerd in opdracht 3? Leq uit waarom wel of niet.

In de lesbrief Secularisatie in Europa speelt secularisatie logischerwijs een explicietere rol. In deze lesbrief komt een aantal van de bovengenoemde punten duidelijker naar voren. Centraal staat het verschil in de mate waarin Europese landen geseculariseerd zijn en een mogelijke verklaring ervan. Secularisatie wordt hier onder andere opgevat als 'het op individueel niveau vervangen van een traditioneel dogmatisch geloof door een meer moderne en persoonlijke manier van geloven.' Om de mate van secularisatie te bepalen, bestuderen leerlingen eerst kaarten met betrekking tot stellingen en vragen 
die aansluiten bij de traditionele religieuze instituties: 'Ik ben een religieus persoon', 'Geloof jij in God?', 'Hoe belangrijk is religie in jouw leven?' en 'Bijwonen van religieuze diensten'. Andere vormen van religiositeit en spiritualiteit, zoals yoga of meditatie, het geloof in 'iets hogers' worden hier niet bestudeerd. Of deze nieuwe vormen echt minder dogmatisch zijn, wordt niet onderzocht.

De lesbrief definieert religie ogenschijnlijk in termen van de traditionele, institutionele godsdiensten. Hoezeer de traditionele kerkelijke instituties in West-Europa ook aan invloed hebben ingeboet, de religieuze ontwikkeling van Europa wordt niet alleen door dat verlies in invloed gekenmerkt. Andere vormen van religiositeit, vaak zonder expliciet godsbeeld, hebben een plek gekregen in de West-Europese religieuze beleving. Het is onduidelijk in welke mate West-Europa daadwerkelijk minder religieus geworden is. Om leerlingen echt te laten nadenken over hun eigen religiositeit moet niet alleen gevraagd worden naar hun godsdienstige beelden en overtuigingen, maar ook naar hun gedrag. Zo zullen West-Europese leerlingen niet zo snel stellen dat ze een amulet gebruiken. Daarvoor heeft de term mogelijk een te grote godsdienstige connotatie. Maar wanneer je vraagt naar speciale objecten, die voor hen een grote betekenis hebben en die ze daarom altijd bij zich hebben als ze een bijzondere uitdaging aangaan, dan zullen meer van hen daarop positief antwoorden. De voor het vak godsdienst/levensbeschouwing relevante vraag kan dan zijn wat het verschil is tussen dat object en bijvoorbeeld het amulet in de vorm van een klein blauw oogje dat veel Grieken met zich meedragen.

Het is daarnaast ook maar de vraag in hoeverre Nederlandse docenten godsdienst/levensbeschouwing de uitleg van de secularisatiethese delen. In de eerder besproken enquête onder docenten godsdienst/levensbeschouwing gaven de respondenten aan het bespreken van levensvragen en religieuze zingeving een van de belangrijkste thema's in hun onderwijs te vinden, belangrijker nog dan het begrijpen van verschillen tussen levensbeschouwingen. Of ze deze vragen bespreken vanuit het perspectief van de leerling, traditionelere religieuze overtuigingen of vanuit nieuwe vormen van levensbeschouwing, wordt niet duidelijk. Als antwoord op dezelfde vraag krijgt het thema geloofsovertuiging nog een waardering van 2,8 . Een belangrijk deel van de docenten acht geloofsonderwijs nog steeds een belangrijk doel van het schoolvak. Daarnaast gaf $68,8 \%$ van de docenten aan zichzelf als religieus persoon te zien. Veel docenten godsdienst/levensbeschouwing lijken een meer traditionele godsdienstige persoonsvorming nog steeds als een belangrijk doel te beschouwen in hun onderwijs. 
Deze docenten zullen niet noodzakelijk de gedachte ondersteunen dat een meer individuele spiritualiteit beter past bij het moderne leven. Eerder wijzen zij op de kritiek op dit secularisatiedenken, zoals verwoord door onder andere Charles Taylor. Taylor (2007) acht de grondgedachte dat het wetenschappelijk denken de wereld bevrijdt van bijgelovig denken - met bijbehorende waarden en normen - onjuist. Religieuze motivatie blijft volgens Taylor een belangrijk gegeven in onze wereld, ondanks dat de institutionele religies aan invloed verliezen (Taylor 2007). Dat deze motivatie niet altijd in traditioneel religieuze termen wordt verwoord, onderstreept Daniel van den Brink. Veel religieuze motivatie is tegenwoordig te vinden in op het eerste gezicht heel aardse bezigheden, zoals werk en vrijwilligerswerk (Van den Brink 2012). Binnen het vak godsdienst/levensbeschouwing zal daarom eerder worden gesproken van een post-seculiere samenleving, waarin religie, weliswaar in getransformeerde vorm, nog steeds een rol van betekenis speelt.

De lesbrieven van het EVE-materiaal lijken dus in meer of mindere mate uit te gaan van een 'grand narrative' - wat de secularisatiethese toch ook is dat binnen het vakgebied godsdienst/levensbeschouwing zeker niet leidend is. De docenten godsdienst/levensbeschouwing zullen de aangeboden lesbrieven dan ook waar nodig moeten aanpassen en aanvullen. Neem bijvoorbeeld een lesbrief als De betekenis van religieuze plaatsen. Hierin wordt de leerling gevraagd na te denken over de speciale waarde van religieuze plaatsen. De docent godsdienst/levensbeschouwing zou kunnen vragen of er ook niet-godsdienstige plaatsen zijn die de leerlingen op een bepaalde manier ook 'heilig' vinden. In hoeverre kan het homomonument in Amsterdam of zelfs het stadion van je favoriete voetbalploeg niet als zodanig worden gezien door bepaalde mensen? Door leerlingen uit te dagen om de heiligheid van plaatsen dichter bij henzelf te zoeken, kan vervolgens wel besproken worden in hoeverre er niet ook een onderscheid te maken valt tussen de beleving van dat homomonument enerzijds en een bedevaartplaats anderzijds.

Om het materiaal van het EVE-project aantrekkelijker te maken voor het schoolvak godsdienst/levensbeschouwing, zou het dus moeten aansluiten bij de wijze waarop de betreffende docenten denken over de waarde van en de ontwikkelingen in Europese religiositeit. Daarvoor zou er in het materiaal meer aandacht moeten komen voor nieuwe vormen van religiositeit en niet-traditionele religieuze waarden. West-Europese leerlingen zijn minder traditioneel religieus, maar dat wil niet zeggen dat ze geheel areligieus te noemen zijn. 


\section{Voorstellen om het EVE-materiaal geschikter te maken voor het Nederlandse levensbeschouwelijke onderwijs}

Gelukkig biedt het aangeboden materiaal voldoende mogelijkheden om deze tekortkomingen op te vangen, mits de docent levensbeschouwing bereid is om bestaande lesbrieven aan te passen of deze zelf te ontwikkelen. Hieronder worden enkele beperkte handvatten gegeven.

Allereerst kan de docent godsdienst/levensbeschouwing zijn lessen opbouwen vanuit de video's. Daarin worden aan verschillende jonge Europeanen vragen gesteld, zoals deze ook in het EVS onderzoek zijn gesteld en zoals deze in de lesbrieven terugkomen. In de video's krijgen jongeren de kans om in eigen woorden uit te leggen wat ze ervan vinden, hoe hun mening vorm krijgt in hun dagelijkse leven en soms ook waarom ze die mening zijn toegedaan. Juist deze video's bieden daarmee de kans om 'andere' Europeanen en hun levensbeschouwelijke waarden beter te begrijpen. De feitenkennis omtrent andere religies, zoals opgedaan in de les kan dan vervolgens worden gebruikt om de eigen woorden van de leerlingen te duiden. In hoeverre sluiten hun meningen aan bij wat het leerboek over die religies zegt? Wat zegt ons dat over de religieuze diversiteit niet alleen binnen Europa, maar ook binnen religies?

Daarnaast bevatten de kaarten van andere categorieën ook stellingen en vragen die gerelateerd kunnen zijn aan levensbeschouwelijke thema's. Zo is er in de categorie 'samenleving' een kaart opgenomen die het percentage mensen aangeeft dat het er (helemaal) mee eens is, dat de mens voorbestemd is om over de rest van de natuur te heersen. Zulke stellingen kunnen ook worden opgevat als levensbeschouwelijke en misschien zelfs religieuze ('voorbestemd') thema's. Wanneer een docent godsdienst/levensbeschouwing de tijd neemt de verschillende kaarten door te lopen, vindt hij een schat aan informatie die ook zeker voor zijn of haar lessen bruikbaar zijn.

Als laatste kan worden aangegeven dat het gebruik van kwantitatieve data in een les godsdienst/levensbeschouwing een meerwaarde kan hebben, zeker wanneer men de data uit verschillende jaren gebruikt. De EVS bevat namelijk data uit 1981, 1990, 1991 en 20087, gegevens die via de kaarten gemakkelijk in historisch perspectief onderling vergeleken kunnen worden. Zodoende kunnen zeker ontwikkelingen op lange termijn, ook op levensbeschouwelijk vlak, inzichtelijk worden gemaakt. Zo laten de kaarten 'geloof in God' in Nederland een gestage daling zien, maar in 2008 blijkt nog $58 \%$ aan in God te geloven. In Polen gaf in 2008 96\% van de respondenten aan in God te geloven en Turkije was dat 99\%. Dit soort kwantitatieve data bieden relevante achtergronden bij de inter-levensbeschouwelijke dialoog, zeker wanneer ingezoomd 
wordt op concretere religieuze thema's als geloof in de hel of in de hemel. De vraag is dan 'welke verschillende waarden kan ik verwachten bij mensen met een andere achtergrond'. Het kan leerlingen laten zien dat het geloof in de hemel en in de hel in Europees perspectief helemaal niet vreemd is, en dat Nederland hierin juist een bijzondere ontwikkeling heeft doorgemaakt. De kaarten kunnen de docent dan ook helpen de inter-levensbeschouwelijke sensitiviteit van leerlingen te trainen.

\section{Conclusie}

Er is veel werk gestoken in het EVE-project. Deze inspanning heeft allereerst een website opgeleverd met veel mooi en bruikbaar materiaal in de vorm van gedigitaliseerde kaarten rond verschillende waarden binnen Europa en in de vorm van video's waarin jongeren hun waarden in eigen woorden verduidelijken. Bij het ontwerpen van de lesbrieven zijn echter nauwelijks mensen vanuit het vak godsdienst/levensbeschouwing betrokken geweest. Dit vak heeft niet alleen een bijzondere status binnen het Nederlandse onderwijs, het heeft binnen de maatschappijvakken ook een eigen benaderingswijze. Deze benaderingswijze komt helaas niet altijd tot zijn recht in de ontwikkelde lesbrieven. Daarvoor leggen de lesbrieven net te veel nadruk op het verklaren van ontwikkelingen en gaan zij meer uit van het verklarende model van secularisatie dan in het vak godsdienst/levensbeschouwing gebruikelijk is.

Met die constatering wil ik niets afdoen aan de waarde van de lesbrieven voor andere vakken. Zelf heb ik in 2011 een handreiking gedaan voor het schoolvak geschiedenis, waarin het verklaren van veranderingen een duidelijke plek heeft. Voor het vak godsdienst/levensbeschouwing zijn wat mij betreft wel enkele aanpassingen nodig. Toch bieden de kaarten en zeker ook de video's voldoende kansen voor dat laatste vak. De docent kan bijvoorbeeld de besproken video's laten zien en leerlingen de opdracht geven om eigen video's over het betreffende onderwerp te maken. De docent kan ook lange termijn ontwikkelingen rond bepaalde religieuze waarden laten onderzoeken en de leerlingen vragen om die ontwikkeling thuis te bespreken. In hoeverre zien zij die veranderingen aan de eettafel thuis terug? Als laatste raad ik collega's dan ook aan de website van het EVE-project eens goed te bestuderen. Ook vragen die op de website van het EVE-project niet als religieus geclassificeerd zijn, bieden informatie die voor de lessen godsdienst/levensbeschouwing bruikbaar kunnen zijn. 


\section{Noten}

1 Een uitgebreide beschrijving van de European Values Study is te lezen in de bijdrage van Inge Sieben in deze bundel.

2 Het ontwikkelde lesmateriaal is gratis verkrijgbaar via de website: www.atlasofeuropeanvalues.eu.

3 De producten van de verschillende ontwikkelteams zijn in te zien via https://curri culum.nu.

4 Deze lesbrief is beschikbaar via: http://www.atlasofeuropeanvalues.eu/new/lesmateriaal.php

5 De wat verrassende titel van de lesbrief verwijst naar een paar van homoseksuele pinguïns in een Duitse dierentuin die samen een ei uitbroedden. Dit voorbeeld vormt de inleiding op de verdere opdracht.

6 Deze opdracht is afkomstig uit de lesbrief 'Is er een plek in de hemel voor iedere pinguin?’ Deze is beschikbaar via: http://www.atlasofeuropeanvalues.eu/new/ lesmateriaal.php

7 De gegevens uit 2017 worden op dit moment nog verzameld, zie ook de bijdrage van Inge Sieben elders in deze bundel.

\section{Literatuur}

Bertram-Troost, Gerdien \& Taco Visser (2017),

Meer zicht op de praktijk. Over inhouden en doelen in de lessen godsdienst/ levensbeschouwing, in: Narthex, 7-10.

Brink, Gabriël van den (2012),

Vindplaatsen van het hogere. Een samenvatting van de belangrijkste bevindingen, in: Brink, Gabriël van den (red.), De lage landen en het hogere. De betekenis van geestelijke beginselen in het moderne bestaan, Amsterdam: Amsterdam University Press, 477-518.

Davie, Gracie, Linda Woodhead \& Rebecca Catto (2016),

Secularism and secularization, in: Woodhead, Linda, Christopher Patridge \& Hiroko Kawanami, Religions in the Modern World. Traditions and Transformations, Londen \& New York: Routledge, 551-570.

Erricker, Clive (2010),

Religious Education. A conceptual and interdisciplinary approach for secondary level, Londen \& New York: Routledge.

Gaans, Gijs van (2018),

Krachtige kennis met 'continuïteit en verandering', in: Béneker, Tine, Toekomstgericht onderwijs in de maatschappijvakken. Een vakdidactisch perspectief vanuit aardrijkskunde, economie, geschiedenis, levensbeschouwing en maatschappijleer, Amsterdam: Landelijk Expertisecentrum Mens- en Maatschappijvakken, 106-121.

Halman, Loek, Inge Sieben \& Marga van Zundert (2011),

Atlas of European Values. Trends and Traditions at the turn of the Century, Leiden: Brill. 
Hamers, Kees (2018),

Dialogisch schrijven, in: Béneker, Tine, Toekomstgericht onderwijs in de maatschappijvakken. Een vakdidactisch perspectiefvanuit aardrijkskunde, economie, geschiedenis, levensbeschouwing en maatschappijleer, Amsterdam: Landelijk Expertisecentrum Mens- en Maatschappijvakken, 89-105.

Krause, Uwe, et al. (2011),

Van onderzoek tot lesmateriaal. European Values Education, Tilburg: FLOT.

McCutcheon, Russell T. (2005),

The Inside/Outsider Problem in the Study of Religion, Londen \& New York: Continuum.

Meyer, H. \& W. Jank (2009),

Didaktische Modelle, (9de dr.), Berlijn: Cornselsen Scriptor.

Phillips, Ian (2008),

Teaching History. Developing as a Reflective Secondary Teacher, Londen: Sage Publications.

Taylor, Charles (2007),

A Secular Age, Cambridge, Massachusetts \& Londen: The Belknap Press of Harvard University Press.

Visser, Taco, Sacha van der Zande, Barbara Schelberg \& Ger van der Heijden (2018),

Kerncurriculumvoorstel vanuit de beroepsgroep, in: Narthex, 5-9. 
